\title{
地域連携による飲食店事業の展開と課題解決
}

一神戸市 W 社と土佐清水市の連携を事例として一

\author{
眞鍋 邦大 1$) *$ 中塚 雅也 ${ }^{1)}$
}

\section{Regional Cooperation in the Restaurant Business: Case Study of Restaurant Chain "W" in Kobe City and Tosashimizu City}

\author{
Kunihiro Manabe ${ }^{1) *} \&$ Masaya Nakatsuka ${ }^{1)}$
}

This study examines the development process and problem solving in the restaurant business through regional cooperation, using a case study of restaurant chain company "W" in Kobe City and Tosashimizu City. Close examination of materials provided by $\mathrm{W}$ and some stakeholder interviews have revealed three points, as important factors of regional cooperation in the restaurant business. The first is business matching by the coordinator キーワード：地域連携，飲食店，連携協定，コーディネーター

\section{1. はじめに}

近年, 農林水産業に掻いては, 他産業との連携を 深めることによって高付加価值化を実現し，所得と 雇用の確保につなげることが求められている。また, 農山村地域の行政に招いては, 都市部にアンテナ ショップをはじめとする交流拠点を設け，地域の特 産品を販売すると同時に，消費者のニーズを把握す るよらな動きが拡がり続けている 1.

一方, 都市側でも, 2000 年代以降, 安心安全な食 を求める消費者の声の高まりに応じて, 地産地消や 産地直送をコンセプトに揭げる飲食店が登場するな ぞ, 産地との関係性を差別化戦略の一つとして強調 する動きも見られるようになってきた，国も，2012 年に策定した「食品産業の将来ビジョン」に扔いて, わが国最大の産業セクターの一つである食品産業に tying an urban and rural community and gradual commercialization. The second is a stable food supply chain and reduction in distribution costs due to regional cooperation. The third is the allotment of appropriate roles depending on the strengths of each actor. This case study shows the possibility of regional cooperation in the restaurant business as a win-win scenario for cooperating businesses.

対して, 生産者と消費者の架け橋となり, 価值連鎖 の形成に貢献することへの期待を寄せている（農林 水産省, 2012).

このように農山村側, 都市側からの相互のアプロー チは強まっているものの, 実態としては一次産業と 外食企業の連携はいまだ活発な状況とは言えず（伊 藤，2012），都市・農山村間の関係主体の連携の拡 大には，な裸題があるのが現状である.

想定される具体的な課題の一つは, 連携主体の マッチングと，それを連携事業として具現化するプ ロセスである。これらについては農商工連携事業な ぞでも繰り返し指摘されているものの, コーディネー ターやプラットフォームの必要性なぞ施策的な指摘 にとどまり，個別具体的な対策や手続きは明らかに されていない。

\footnotetext{
1) 神戸大学大学院農学研究科; Graduate School of Agriculture, Kobe University

* E-mail: kunihiro.manabe@gmail.com 
二つ目の課題は, 安定的な食材の供給体制の構築 と流通コストである. 櫻井（2010）などの指摘を待 つまでもなく, 遠隔地の単一産地との直接取引にお いては, 常にこうした問題に直面する.

それらを踏まえた上で，第三に課題となるのが， 連携する主体間の適切な役割分担である. 各主体の 強みと弱又を相互に補完する役割分担のあり方を示 すことが求められている.

以上のことから本稿では, 都市部の外食企業が農 山村の生産者や商工団体, 行政などと連携して取り 組む飲食店事業を事例として取り上げることにより， 連携による飲食店事業の実態を各主体の関係性を中 心に明らかにするとともに, 先に示した課題解決の 方策について分析することを目的とした．事例とし て取り上げるのは，兵庫県神戸市に本社を置く株式 会社 $\mathrm{W}$ 社（以下, $\mathrm{W}$ 社）である. $\mathrm{W}$ 社は, 複数の 地域と連携しながら, 異なるブランドで複数の飲食 店を展開しているが，本稿では最も関係が長期に渡 り, 広範な展開を見せている土佐清水市との連携事 業を分析対象とした.

研究の方法としては，上述の視点と目的のもと， $\mathrm{W}$ 社から提供されたデータおよび資料を精査した上 で，各主体への聞き取り調査を実施した。W 社へ は, 担当者へのヒアリングを中心に行った 2017 年 6 月拉よび 8 月の 2 回と, 代表取締役へのヒアリン グを中心に行った 6 月の計 3 回の訪問に加光, 適宜

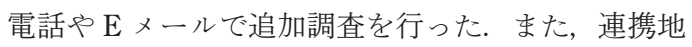
域である土佐清水市へは，2017 年 9 月に訪問をし， 現地の主要な関係主体である, 土佐清水市観光商工 課, 土佐清水商工会議所, 窪津漁業協同組合, 高知 県漁協清水統括支所, 新谷商店らへ, 聞き取り調査 を実施した。

\section{2. $W$ 社と土佐清水市の連携事業}

\section{(1) 対象事例の概要}

\section{1）株式会社 W}

$\mathrm{W}$ 社は, 兵庫県神戸市に本社を置き, 「土佐清水 ワールド」などの飲食店 24 店舗（2017 年 9 月末時 点）を運営する外食企業である. 会社の設立は 1996 年であるが，現在中核となっている飲食店事業の開 始は 2002 年であり, 以後, 年に平均 1 店舗のペー

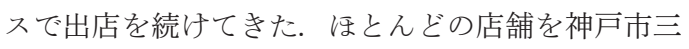

宮周辺に集中的に出店する戦略は $\mathrm{W}$ 社の特徴の一 つである ${ }^{2}$ 「食によって，郷土と地域をつなぎ， ニッポンの風景を熱くする」の理念のもと，飲食店 の立場から地域の課題解決に向き合ら姿勢を当初よ り示して和り，近年は，店舗運営のみならず，イン ターネット通販や B to B での食材流通, 生産者と連 携した商品開発など，食を基軸とした事業展開を進 めている.

店舗の内訳は, $\mathrm{W}$ 社が地域連携協定店もしくは地 域連携強化店と呼び, 生産者に加光自治体との緊密 な連携をべースに，特定地域の食材を提供するとと もに店頭に物販や情報発信のスペースを設け，アン テナショップとしての機能も有する飲食店（以後, 地域連携型）が 10 店舗，それ以外の鄉土料理店が 14 店舗である.

地域連携型の業態は, 2015 年度より展開を開始 乙, 土佐清水市, 青森県, 山陰地方（島根県 - 鳥取 県）と連携先を増やしながら ${ }^{3}, 2017$ 年 9 月末時点 で 10 店舗を数えている. 図 1 亿直近 7 年間（11月 期決算）の W 社の店舗総売上の推移を示した. 2016 年度の店舗総売上は約 15 億 9,100 万円，そのうち地 域連携型の総売上は約 4 億 9,800 万円となっている. 2017 年度の売上は 9 月末までの 10 ヶ月間の数值で あるが，地域連携型の売上はすでに約 7 億 6,600 万 円と前年度を超える成長を見せている.

また，W 社は全店舗を対象としたポイントカード システムを導入して拉り，現在会員数は 7 万人を超

（百万円）

（店舗）

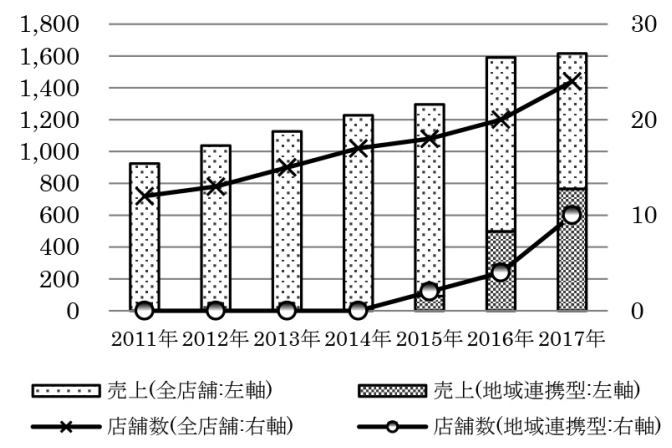

図 $1 . \mathrm{W}$ 社の売上と店舗数の推移 資料 : $\mathrm{W}$ 社の内部資料より, 筆者作成.

1）決算年度は, 12 月から翌年 11 月までの 1 年間.

2) 2017 年度は， 9 月末までの 10 用間の数値. 
える。そのらち， 1 年に 2 度以上，店舗に足を運ん だ会員には無料で月刊の会員情報誌を送付して抒 り，W 社と顧客をつなぐ貴重な情報伝達手段となっ ている. 現在の発行部数は約 2 万部である.

\section{2）土佐清水市（高知県幡多地域）}

土佐清水市は, 高知県の西南部, 四国の最南端に 位置し, 北は四万十市と三原村, 西は宿毛市と大月 町に隣接している. この 5 市町村に, 四万十市の東 に隣接する黒潮町を加えた 6 市町村で幡多（はた） 地域を形成している.

市の面積は, $266.34 \mathrm{~km}^{2}$ で, ほぼ全域が足摺宇和 海国立公園に含まれる。黒潮が近海を流れることか ら, 古くから水産業を基幹産業として発展し, 清水 漁港は現在も県内有数の水揚げ高を誇っている. と りわけ，足摺岬沖の岩礁域で一本釣りされた大ぶり のゴマサバは「清水さば」といらブランド名で県内 外に販売されて招り, また, マルソウダ（高知県内 ではメジカと呼ばれる）を原料とする宗田節の生産 量では日本一となっている. 人口は， 3 万人を数光 た 1950 年代のピーク時から半減し， 2017 年 8 月現 在で 14,108 人, 世帯数 7,466 世帯, 高齢化率は 45.9\%となっている4.

\section{（2）連携による飲食店事業の概要}

$\mathrm{W}$ 社と土佐清水市の各主体の連携による飲食店事 業は，「土佐清水ワールド」といらブランドで展開さ れている，特産品である清水さばやカッオ，長太郎 貝など，土佐清水沖で獲れた新鮮な海産物を神戸市 に直送し，各店舗で郷土の味を提供している. 2015 年 6 月に 1 号店を開店したが，それに先立って締結 された地域連携協定に基づき, 店内には特産品の販 売コーナーが併設されて沏り，アンテナショップと しての機能も果たしている. 土佐清水ワールドへの 高い評価を背景に, 2017 年には, 幡多地域 6 市町村 の活性化を目的とした新業態の「土佐清水ワールド 幡多バル」の営業を開始するなど，積極的な店舗展 開を続けている。 2017 年 9 月末時点で神戸市内に 5 店舗, 東京都内で 2 店舗の合計 7 店舗が運営されて 扣り，表 1 に示寸通り，2017 年度の売上高は 9 月末 までの数字で約 5 億 8,600 万円となっている.

店舗が順調に営業を続ける中，2017 年には新たな 取り組みとして W 社と土佐清水市との共同企画によ る土佐清水訪問ッアーが実施され，W 社の常連客な
表 1. 土佐清水市との連携店の売上と店舗数の推移 (上段単位：千円）

\begin{tabular}{c|c|c|c}
\hline \hline & 2015 年度 ${ }^{1)}$ & 2016 年度 & 2017 年度 ${ }^{2)}$ \\
\hline 売上 & 92,289 & 407,757 & 586,675 \\
\hline 店舗数 & 2 & 3 & 7 \\
\hline
\end{tabular}

資料：W 社の内部資料より, 筆者作成.

1）決算年度は， 12 月から翌年 11 月までの 1 年間.

2） 2017 年度は, 9 月末までの 10 ヶ月間の数值.

ど約 20 名が参加した. また, その秋には土佐清水市 民が神戸の土佐清水ワールドを訪問するッアーが実 施され，店舗を超えた相互交流も生まれつつある。

\section{3. 連携の契機と飲食店事業の展開プロセス (1) 連携の契機}

連携の契機は, 2010 年 11 月, 土佐清水商工会議 所の経営指導員（当時）であった $\mathrm{T} 氏$ 氏，W 社をよ く知るコンサルタントのI氏が広島県で開催された セミナーで出会ったことと言われる，当時，地域経 済の縮小を背景に，T 氏は会員事業者の県外での販 路開拓の支援に取り組んでいた，食を通じた地域の 課題解決といら理念の下にW 社が「長門フェア 5 」 を開催しているといらことを知った $\mathrm{T}$ 氏は，すぐに $\mathrm{W}$ 社にコンタクトを取っている. 以降， $\mathrm{T}$ 氏は「土 佐清水フェア」の開催を念頭に，熱心に W 社への情 報提供を続け， 2012 年 1 月に，W 社の $\mathrm{K}$ 社長を含 むスタッフ 4 名の初の土佐清水市訪問が実現した. その際，T氏は 3 日間で宗田節加工業者など約 10 の 生産現場を案内した上で，W 社と生産者の交流会を 企画するなど，顔の見える関係を作り出すための現 地コーディネートを行っている. 結果的には, この 訪問以降現在に至るまで, 年に $1 \sim 2$ 回の頻度で土佐 清水市の生産者と W 社のスタッフが双方の現場を行 き来する関係性が継続している.

このよらに，マッチングにおいては，まずW 社の 理念と商工会議所の外商二ーズが合致した点が挙げ られるが, 生産者を束ね, 産地と W 社間のコミュニ ケーションハブとなり，人的な交流を支えた T氏の 存在が，継続的な関係の構築に大きく寄与している.

\section{（2）イベント試行と実店舗開店}

初訪問に沶いて土佐清水市の食材と生産者の想い に感銘を受けた W 社は，すぐに「土佐清水フェア」 
の企画を始め，翌月には既存店舗でのフェアを実現 している. 先の訪問で交流のあった生産者の商材は 全て取引されたが，消費者の反応が予想以上だった ことから，フェアは年に 1 回の定例的なイベントと なり，季節を変えて毎年開催されることとなった。 また, フェアとは別に, 既存店舗でも土佐清水沖の 鮮魚やだし滰油などが扱われるようになり, 複数の 生産者と W 社の継続的な取引が始まっている.

土佐清水市に特化した飲食店を作るといら話が浮 上したのは， 2015 年 1 月の数度目となる $\mathrm{W}$ 社の現 地訪問の際である.フェアや店舗での食材の評判の 良さから，会食の席に打いて実店舗開設への言及が あった。 まなくして神戸市で適当な物件が見つか り， $\mathrm{K}$ 社長からその報せを受けた $\mathrm{T}$ 氏は，地元で核 となる 5 人のメンバーに意思確認を行い, 全員の意 見が一致したことで，土佐清水に特化した飲食店の 構想が具体的に動き始めた。 3 月上旬には，その 5 人が商品提案書を携えて W 社を訪問し,メニューの 検討が始まっている，また，新店舗の名称は最終的 に「土佐清水ワールド」に決まり，2015 年 6 月 17 日, $\mathrm{W}$ 社と土佐清水市の連携による飲食店の 1 号店 が三宮に開店した。

以上のように，フェアは各々の食材に対する消費 者の反応を確認するためのテストマーケティングの 機会として機能して扔り，またフェアを繰り返すこ とで, 新メニューの開発や食材の集荷, 輸送方法の 改善の機会としても活かされている. このような段 階的な事業化は, 実店舗の開店という大きな投資に 対して，リスクを軽減する効果を発揮している.

\section{（3）地域連携協定の締結}

連携が進展する過程で考案されたのが，地域連携 協定の締結である. 実店舗の開店を前にして K 社長 より T 氏へ提案があり， T 氏が仲介する形で土佐清 水市への打診が行わ机ている。市では他県の事例を 参考に表 2 のよらな連携項目を作成し, 市長の全面 的な支援のもと，2015 年 5 月 11 日に土佐清水市と $\mathrm{W}$ 社の地域連携協定が締結された。協定では，土佐 清水市から $\mathrm{W}$ 社への食材提供の久ならず，W 社が 地域の情報発信や観光 PR 沶よび地元への誘客を実 践することなどが定められている。 このとき，前例 のない地域連携協定を進める上で重要だったのが, $\mathrm{W}$ 社の姿勢と実績である。市としては, 行政におけ
表 2. 地域連携協定の一部拔粋

(目的) 第 1 条甲と乙 ${ }^{1)}$ は，緊密な相互連携により，神戸 市に拈けるアンテナショップ機能を有する拠点として, 乙 が運営する飲食店（以下「店舗」と称する.）の活用を推 進し，地域の活性化を図ることを目的とする

(連携事項) 第 2 条甲と乙は, 前条の目的を達成するた め, 次の事項について連携, 協力する。

（1）食材提供の積極的な活用，流通に関すること

(2) 観光 PR と誘客活動に関すること

(3) 農産物等の産直システム構築に関すること

（4）食文化の情報発信に関すること

（5）関西圏でのイベント等の情報発信に関すること

(6) 移住の PR 活動に関すること

(7) 特産物, 郷土料理, 地酒に打ていの魅力的なメニュー 提供に関すること

(8) 郷土の祭り，民謡，歴史，文化等の紹介に関する こと

（9）大規模災害時の応急復旧活動に関すること

(10） HP，広告，広報，など PR 活動に関すること

（11）その他店舗を活用した活動に関すること

資料：W 社の資料より，筆者作成.

1）甲は土佐清水市，乙は $\mathrm{W}$ 社.

る公共性, 公平性の観点から W 社のような地域外の 企業と個別に連携を結ぶのは容易ではない。しかし ながら，W 社が商取引だけでなく継続的に人的な交 流を行っていたこと，また市内の特定事業者のみと 取引をするのではなく農産物等へと取り扱いの幅を 拡げていたことなど，長期に渡って積み重齐た実績 が，広く土佐清水市の活性化に資する企業との評価 につながり，協定が実現した。

このよらにして締結された連携協定は，W 社に とっては消費者に対して産地との強い関係性を示寸 シンボルの役割を果たし，土佐清水の各主体に対し てはコミットメントを示すことになり，さらなる信 頼の醇成に寄与した，一方で，行政にとっても政策 的な支援を行う際の後ろ盾として活用できるなど， 各方面に执いて好循環が生まれている.

\section{4. 食材供給体制と流通}

\section{（1）食材供給を安定化する取り組み}

鮮魚の取引においては，W 社はある程度の量のみ を指定した発注を行い，魚種の選定を漁協に一任寸 ることで，漁獲の変動に伴ら産地側の負担を減じて 
いる。また，消費地に扔いては三宮周辺に集中的に 出店し, 産地からの食材を一旦セントラルキッチン に集約した上で，各店舗に配送することで，各店舗 での需要の増減に対して, 店舗間で需給の調整を行 い，柔軟に対応できる体制を整えている.

また, 初回のフェアの頃には 20 種類汪どだった取 扱商品は, 現在では鮮魚, 青果, 宗田節や調味料な どの加工品, 約 100 種類にのぼっているが, 市場で はなく生産者との直接取引によって主な食材を調達 する土佐清水ワールドに执いては, 店舗の増加に伴 い, 生産者の開拓や食材の探索を継続的に行う必要 があった. この点に拈いては, 地域にネットワーク を有する T氏が中心となり, 行政や生産者と連携し ながら, 新たに必要となる食材や生産者の情報を提 供することで, 店舗の増加とともに土佐清水との取 引量を増大させていった，店舗網が拡大する中で, 土佐清水市と $\mathrm{W}$ 社の取引は年々増加し, 2017 年 9 月時点で, 土佐清水市と $\mathrm{W}$ 社の食材の取引量は月間 約 1,500 万円に達し, 常時約 20 の生産者が $\mathrm{W}$ 社に 出荷している.

このように, 不安定な漁獲に伴ら産地側の負担に 関しては W 社が積極的に吸収し，一方で食材の探索 に関しては産地側が協力することでW 社の負担を抑 えるなど, 双方の強みを生かすことで持続的で安定 的な食材供給の関係を構築している.

\section{（2）活魚車の導入}

流通面では, 加工品に関しては土佐清水で集約す る動きも生まれつつあるが, 基本的には個々の生産 者や事業者から W 社へ直送されている. その中に括 いて特徵的な動きは活魚車の導入である. その背景 には, 従来から提供していた絞めた状態の清水さば ではなく，より郷土の味に近いものを都市部の消費 者に提供したいといら産地側の要望があった. 2016 年 3 月, 3 号店の開店計画に合わせ, 行政と高知県 漁協清水統括支所が協力し, 活魚車の導入が決定さ れた. 加えて, 新店舗には大型の生けすが設置され, 活魚の清水さばを神戸に輸送できる体制が整った. 費用の約 1,500 万円は，市が国の地方創生交付金を 活用し, 活魚車の所有者となる高知県漁協清水統括 支所飞全額補助した。運行に係る経費に执いても， 特産品のPR という目的において, 当初は一部が公 的な資金によって補助されている.
表 3 . 各主体の役割分担

\begin{tabular}{|c|c|c|c|c|c|}
\hline & & $\mathrm{W}$ 社 & 市役所 & $\begin{array}{l}\text { 商工 } \\
\text { 会議所 }\end{array}$ & $\begin{array}{l}\text { 生産 } \\
\text { 者 } 1)\end{array}$ \\
\hline \multirow{5}{*}{$\begin{array}{l}\text { 出店 } \\
\text { 計画 }\end{array}$} & コンセプト作り & $\bigcirc$ & $\bigcirc$ & $\bigcirc$ & $\bigcirc$ \\
\hline & 立地調査 & 0 & & & \\
\hline & 物件取得 & $\bigcirc$ & & & \\
\hline & 店舗デザイン & $\bigcirc$ & $\bigcirc$ & 0 & $\bigcirc$ \\
\hline & 改修 & $\bigcirc$ & & & \\
\hline \multirow{4}{*}{$x=ュ-$} & マーケット調査 & $\bigcirc$ & & & \\
\hline & 食材研究 & 0 & & 0 & 0 \\
\hline & $x=ュ$ 開発 & $\bigcirc$ & & $\bigcirc$ & 0 \\
\hline & 原価管理 & 0 & & & \\
\hline \multirow{3}{*}{ 仕入 } & 食材探索 & & O & $\bigcirc$ & 0 \\
\hline & 仕入交渉・購買 & $\bigcirc$ & & & \\
\hline & 供給（各店舗へ） & $\bigcirc$ & & & \\
\hline 調理 & 食材調理 & 0 & & & \\
\hline \multirow{3}{*}{$\begin{array}{l}\text { 店舗 } \\
\text { 運営 }\end{array}$} & フロアサービス & 0 & & & \\
\hline & 従業員教育 & $\bigcirc$ & & & \\
\hline & 店舗維持管理 & $\bigcirc$ & & & \\
\hline \multirow{5}{*}{$\begin{array}{l}\text { 販売 } \\
\text { 促進 }\end{array}$} & 地域情報収集 & & $\bigcirc$ & $\bigcirc$ & $\bigcirc$ \\
\hline & 情報発信 & $\bigcirc$ & $\bigcirc$ & $\bigcirc$ & $\bigcirc$ \\
\hline & 販促物 & $\bigcirc$ & O & O & \\
\hline & 広告宣伝 & $\bigcirc$ & & $\bigcirc$ & \\
\hline & 広報 & 0 & 0 & & \\
\hline
\end{tabular}

資料 : 齋藤・清野（2014）を参考に聞き取り調査より筆者 作成.

1）生産者は, 鮮魚の出荷者である窪津漁協や高知県漁協清 水統括支所，新谷商店らを指す。

以上，流通面に打いても，地域連協定を背景に， 行政が公的な負担によって土佐清水の事業者と $\mathrm{W}$ 社 の連携の取り組みを支援して和り，結果，これまで 四国内でしか扱われていなかった活魚の清水さばが 神戸市内で提供可能になるなど，店舗の付加価值化 に貢献している.

\section{5. 地域連携における役割分担}

$\mathrm{W}$ 社と土佐清水市の地域連携による飲食店事業に おける各主体の役割分担について, 齋藤・清野 （2014）で示されるフードサービス業の構成機能を 参考に整理したのが表 3 である.

まず出店計画に颃いては，店舗内への生けすの導 入や宗田節に特化した店舗の開店など, 連携が深ま るにつれて，コンセプト作りや店舗デザインに地域 
側の意見が反映されるよらになっている.

立地調査やマーケット調査など, 消費者の動向に 直結する都市部の情報取得はW 社が担っているが, 店舗で提供する食材やメニューに関しては，できる 限り郷土の味に近づけたいといら W 社の意向から， 商工会議所や生産者らも積極的にアイデアを提供し ている. 一方, 食材の探索に関しては, 現地に強固 なネットワークを持つ商工会議所が中心となり, 市 役所の農林水産課や生産者らと連携しながら, 食材 の提供者をとりまとめて W 社に紹介している.

仕入，調理，フロアサービス等の飲食店に打ける 基幹的な業務と，物件取得や店舗改修，賃料や光熱 費負担などの店舗維持管理は W 社が行らが, 販売促 進に関わる各業務に関しては，地域側との強い協力 体制が築かれている. 産地側の各主体が収集した地 域の情報は $\mathrm{W}$ 社をはじめ各主体が共有しながら WEB 等で積極的に情報発信をし，広報や広告宣伝に 関しては, 自治体が地元の報道関係者や県人会への 案内を担当し, $\mathrm{W}$ 社が主に都市部のマスメディアに 広報している.

このように, 立地調査や物件取得, 店舗運営など,
飲食店としての基幹的な業務は従来どおり W 社が担 当しているが，とりわけ食材探索や地域情報発信な ぞ，産地が強みを発揮できる業務に打いては，土佐 清水市の各主体への機能分担が行われている. また, 店舗デザインやメニュー開発に産地側が携わること で，W 社単独では困難な郷土の風景や味の再現が可 能となり，消費者への訴求力につながっていると考 えられる。広報に関しても，W社が都市部，行政が 産地側を担当することで，双方が単独ではアクセス 困難な層への周知が可能となり，店舗の集客力に寄 与したと考觉られる。

\section{6. まとめ}

\section{（1）各主体の連携関係}

以上の分析結果を踏ま光, $\mathrm{W}$ 社と土佐清水市の主 体間の関係を示したのが図 2 である．前節で示した フードサービス業の役割分担に関しては，食材研究 やメニュ一開発，食材探索に扣いて，生産者や商工 会議所から W 社への情報提供が行われている。 た，行政も，W 社に対して食材探索や地域情報の提 供を行っている．W 社は，店舗運営と同時に，販売

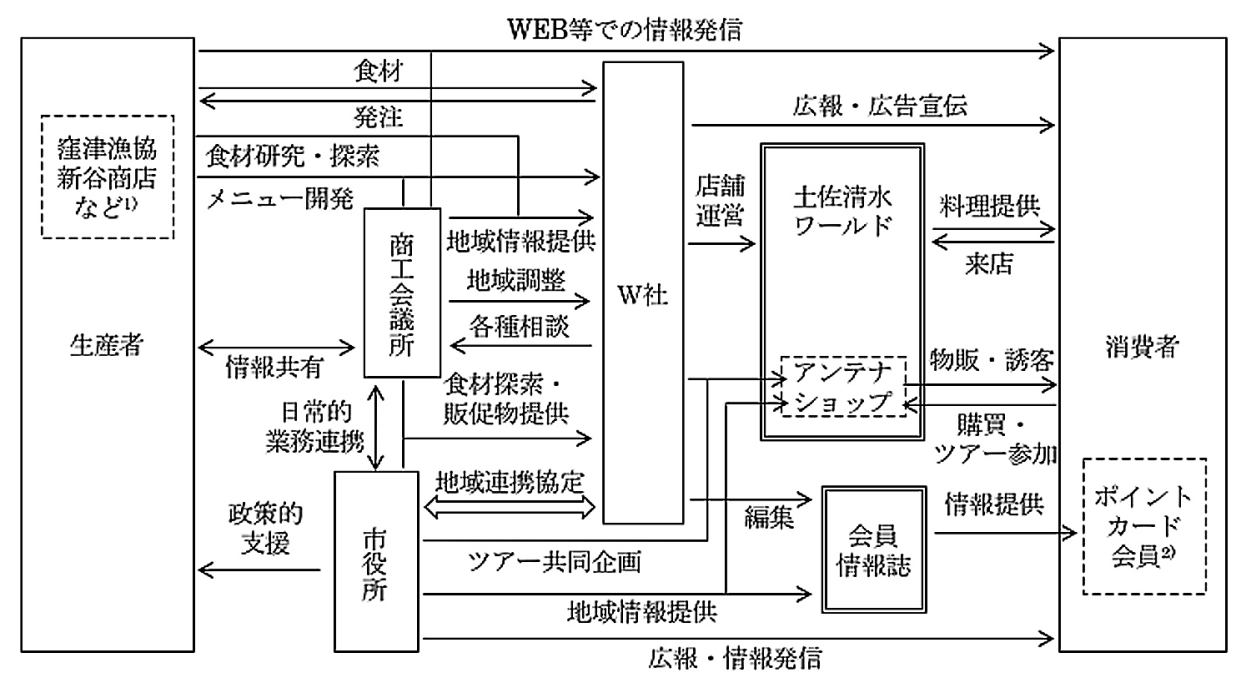

図 2. 地域連携による各主体の連携関係

資料：聞き取り調査より筆者作成.

1）生産者の中で核となるメンバーが。食材提案等を行った。

2）ポイントカード会員のらち，1年に 2 度以上，店舗に足を運んだ会員に無料で月刊の会員情報誌が送付される.

3）実線は各主体，二重線は $\mathrm{W}$ 社の事業を表す。 
促進のための広告宣伝を行っているが，情報発信や 広報に関しては，産地側の各主体も各々が持つネッ トワークに情報を提供することで, 店舗への集客に つなげている。 その他，W 社と行政は，会員情報誌 の作成やッアー企画を共に行っており, 店舗運営を きっかけに連携が拡がりを見せている.

\section{(2) 連携課題への対応}

以降では，本稿で設定した連携課題について，W 社ならびに土佐清水市の各主体の対応を改めて整理 するとともに, 今後の連携展開への要点として考察 を加えながらとりまとめる。

(1)マッチングと事業化の課題に関してであるが, マッチングに扣いては, 産地と外食企業のコミュニ ケーションの基点となる仲介者の存在がとりわ和重 要である。仲介者が, 双方のニーズを汲み取り, 調 整を行い, 継続的な人的交流の基盤となることで, 各主体間の信頼の醸成が促進される，そのように構 築された信頼を担保し，連携を持続するためには， 協定のよらな明示的な承認が，関係主体間のみなら ず対外的にも非常に有効であろう。事業化のプロセ スでは，イベント等での試行を通じた，段階的なプ ロトタイピングがリスクの低減に効果的であると考 えられる。

(2)食材供給体制と流通の課題に関しては, まず産 地の負担を軽減するために, 発注や加工, 調理など いずれかの段階において需給のミスマッチを調整す る仕組みが必要である。そういった仕組及を用意し た上で，食材の探索や生産者の開拓で産地との協力 体制を築けば，安定的な食材供給が期待できる，流 通面での政策的な支援は，遠隔地との取引であれば あるほど消費者への付加価值の提供につながり, 差 別化戦略の一つとして有効に機能すると考兄られる.

(3)役割分担の課題に関しては，飲食店の業務のら ち, 地域の情報に関連する部分に扔いては産地の各 主体に役割を分担することで，各々の強及が発揮さ れる。 また，各主体によって異なるネットワークを 有する場合には，それぞれが広報や情報発信を行う ことで，連携全体での発信力の強化につながる.

以上のように，地域間の連携に打いて想定される 課題に対して, W 社ならびに土佐清水市の各主体は 解決の方策を生み出し, 連携による飲食店事業とし て一定の成果を挙げている，さらには新たな動きと
してッアーの実施も見られ, $\mathrm{W}$ 社と土佐清水市の連 携は, 店舗を単なる食材提供の場から, 農山村と都 市を結ぶ交流の場へと変化させつつあると見ること もできる。

$\mathrm{W}$ 社では, 土佐清水市との連携を契機として，青 森県や山陰地方へと地域連携が拡がりを見せている. 都市部での販路拡大や人的交流に課題を抱える農山 村地域と, 生産者との関係を強めることで競争力強 化を図りたい外食企業の双方にとって，地域連携に よる飲食店事業は今後の展開を期待できるビジネス モデルであると言えよう，特に，独自にアンテナ ショップや交流拠点を持つことが困難な小規模な自 治体にとっては，都市部での有効な戦略の一つとな りらる.

しかしながら，本稿では，土佐清水市と $\mathrm{W}$ 社の連 携といら限定的な範囲での展開を分析するにとど まって和り，想定される課題への対応が，汎用性を 持った解決策であるかは現時点では確認できていな い. 地域間の比較分析による展開要因の抽出を今後 の課題としたい.

\section{注}

1 一般財団法人地域活性化センターが発表した「平成 28 年度 自治体アンテナショップ実態調查報告」によると, 2016 年 4 月 1 日現在の東京都内の店舗数は 65 を数え, 2001 年以降, 増加の一途をたどっている.

2 店舗立地の内訳は, 神戸市内に 21 店舗, 東京都内に 2 店舗, 大阪市内に 1 店舗であり, 神戸市内の店舗は三宮・元町周辺 に集中している.

3 山陰地方とはまだ連携協定は締結していないものの, W 社は 地域連携強化店と名づけ, 地域連携協定を締結済みの土佐清 水市と青森県と同業態に位置づけている.

${ }^{4}$ 土佐清水市の面積や人口に関する数值は, 土佐清水市 (2015) より最新の情報を引用した.

5 長門は，山口県長門市のことである. W 社は，当時から関係 のある地域から産地直送の食材を仕入れ，既存店舗でフェア を開催していた。

\section{引用文献}

伊藤匡美（2012）「外食企業と生産者の連携の形態と成果」『日 本フードサービス学会年報』17, 6-23.

齋藤文信・清野誠喜（2014）「フードサービス業におけるバイ ヤー機能を構成する要素の担い手の変化一メニュー開発・ 調理機能との連携関係に着目して一」『農林業問題研究』 50(2), 81-86. 
櫻井清一 (2010)「農・工・商・官・学の連携プロセスをめぐ る諸問題」『フードシステム研究』17(1), 21-26.

土佐清水市（2015）「市政情報」（https://www.city.tosashimizu. kochi.jp/kurashi/outline/) [2017 年 10 月 1 日参照 . 農林水産省（2012）「食品産業の将来ビジョン」（http:// www.maff.go.jp/j/press/shokusan/ryutu/pdf/120330-01.pdf ) [2017 年 11 月 1 日参照]. 